\title{
Economic impact assessment of Turkey's post-Kyoto vision on emission trading
}

\author{
Gökçe Akın Olçum a,*, Erinç Yeldan ${ }^{\mathrm{b}}$ \\ a Department of Economics, Bilkent University, Ankara 06800, Turkey \\ ${ }^{\mathrm{b}}$ Department of Economics, Yașar University, İzmir, Turkey
}

\section{H I G H L I G H T S}

- We conduct welfare analysis of Turkey's post-Kyoto vision on emission trading.

- Welfare impacts of having Turkey in the EU ETS via EU accession are analyzed.

- Analysis is done with the current EU target of $20 \%$, and the revised target of $30 \%$.

- Welfare impacts of linkage on both regions highly depend on the emission targets.

- The EU has welfare gains when Turkey engages in abatement actions.

\section{A R T I C L E I N F O}

\section{Article history:}

Received 28 July 2012

Accepted 8 May 2013

Available online 30 May 2013

Keywords:

Climate mitigation policies

Emission trading systems

Applied general equilibrium modeling

\begin{abstract}
A B S T R A C T
For the post-Kyoto period, Turkey strongly emphasizes the establishment of national emission trading system by 2015 and its integration with the EU ETS along its accession process to the EU. In this paper, we study the mechanisms of adjustment and economic welfare consequences of various ETS regimes that Turkey considers to apply by 2020, i.e. regional ETS and international trading within the EU ETS. We conduct our analysis under the current EU 20-20-20 emission target, 20\%, and also under its revised version, 30\%. We find that Turkey has economic gains from linking with the EU ETS under the $20 \%$ cap, in comparison to the domestic ETSs. Despite the EU's welfare loss under linkage in comparison to the case where Turkey has domestic abatement efforts, it still prefers linking as it increases economic well being compared to the case where Turkey does not abate. Under 30\% cutback, Turkey has critical output loss under linkage due to high abatement burden on the $\mathrm{EU}$, while the EU is better off as it passes some of its abatement burden to Turkey. Therefore, emission quotas and their allocation across the ETS and non ETS sectors become highly critical in distributing the overall economic gains from bilateral trading.
\end{abstract}

(c) 2013 Elsevier Ltd. All rights reserved.

\section{Introduction}

Following its removal from the Kyoto Protocol's Annex B list, Turkey did not follow any official emission reduction targets over the period, 2008 and 2012. For the post-Kyoto period, the Ministry of Environment and Urbanization (MEU) delivered Turkey's national vision within the scope of climate change in the National Climate Change Action Plan: 2011-2023 (Ministry of Environment and Urbanization, 2011). Within this document, Turkey's objectives are stated as becoming a country fully integrating climate change related objectives into its development policies, improving energy efficiency, increasing the use of renewable energy sources, and decreasing its emissions. In stabilizing $\mathrm{CO}_{2}$ emissions, the

\footnotetext{
* Corresponding author. Tel.: +1 6175832207.

E-mail address: gokceakin@gmail.com (G. Akın Olçum).
}

Action Plan strongly emphasizes the establishment of national emission trading system in Turkey by 2015 and its integration with the existing and new global and regional carbon markets. Turkey has also showed its determination in participating in global carbon markets with the opening of the Environment Chapter as part of the EU enlargement process. Turkey is expected to integrate with the EU ETS along its accession process to join the EU. Besides setting the international political agenda, as being world's largest international carbon market, the EU ETS provides a natural venue for Turkey in establishing its national permit market and a potential partner for international carbon trading.

Having started in 2005 with a trial period, the EU ETS completed its second phase during 2008-2012, and is at the onset of its third phase between 2013 and 2020, compatible with the EU 20-20-20 targets (European Commission, 2008). For the postKyoto period, the EU strongly supports an effective global carbon market and encourages establishing direct links between the 
EU ETS and other cap-and-trade systems. The third countries neighboring the $\mathrm{EU}$, together with the candidate and potential candidate countries, are stated as the most potential trading partners (European Commission, 2009).

Bottom-up linking of cap-and-trade schemes are highly desirable as it enhances price equalization across the linked schemes resulting in reduced aggregate abatement costs compared to ex ante abatement costs (Haites, 2001; Blyth and Bosi, 2003). In addition, both Turkey and the EU are supposed to benefit from the proper functioning of the carbon market due to increased liquidity and decreased price volatility (Baron and Bygrave, 2002). Nevertheless, overall efficiency gains do not necessarily translate into regional efficiency gains. Linking the EU ETS with the Turkish national permit market can have various distributional impacts, which strongly depend upon the design of permit trading scheme, existing distortions in the economies, carbon intensity of the economies, and further on the terms of trade effects that the regions are exposed to via international trade. Therefore, the regional efficiency gains should be analyzed in a way that accounts for these various price and income effects.

Despite incentives provided in the political background, there remain many challenges that both Turkey and the European Union face in formalizing their post-2012 abatement strategies based on permit trading. Previous modeling efforts on the Turkish abatement strategies against greenhouse gas emissions have exclusively focused on applications of taxation in the Turkish economy in isolation from the global economy. Telli et al. (2008) and Vural (2009) concentrated on the taxation of energy use as instruments of carbon dioxide abatement while Kumbaroglu (2003) focused on the taxation of sulfur emissions. In a more recent study by Aydin and Acar (2010), the economic impacts of unilateral carbon taxation in Turkey are investigated under the case of Turkey's accession to the European Union.

The economic aspects of bottom up linking of the EU ETS with other cap-and-trade systems have been assessed in various model frameworks. In their theoretical study, Eyckmans and Hagem (2011) show that the EU countries can benefit from the bottom up linking of regional cap-and-trade systems in case of certain trade agreements. They test their hypotheses in using numerical simulation methods across EU and China for 2015. In another study, Anger (2008) studies linking the EU-ETS with the newly emerging market schemes beyond Europe, i.e. Japan, Canada, the US and the OECD Pacific countries. Their numerical analysis shows that linking the EU-ETS with the emerging permit markets induces minor economic benefits for the EU, while the economic impacts for the non-EU countries can vary depending on the nature of domestic structural differences and prevalent inefficiencies. The dependence of the economic impacts to the structure of allowance allocation in the linking permit trading schemes is further analyzed in Anger (2009).

Thus, there is a gap in the previous literature in addressing the economic impacts of Turkey's abatement policies and bottom-up linking of the EU ETS with the emerging Turkish permit market during the post-Kyoto period. This paper aims to fill this gap and analyze the unilateral use of emission trading schemes in Turkey as part of its contribution to the international climate change mitigation efforts. It further investigates the economic impacts of linkage provisions on both the EU and Turkey, which is planned to take place as part of the EU's enlargement policies in the post-2012 period.

To this end, we build a multi-regional, multi-sectoral applied general equilibrium model in order to study the economic impact of Turkey's market-based abatement policies on the respective economies. Our analysis shows that the EU prefers that Turkey abates at home rather than not, while Turkey finds domestic abatement costly. However, Turkey can alleviate some of these costs by bilateral trading within the EU ETS. The economic gains out of permit trading are highly dependent on the total emission targets and their allocation across sectors. Our analysis further suggests that in the case of an increase in the EU's emission target, Turkey would not prefer to trade permits with the EU but rather stick to domestic abatement policies.

Under 20\% cutback, Turkey has economic gains under bilateral trading within the EU ETS in comparison to unilateral trading schemes. Although the EU has certain level of welfare loss under bilateral trading in comparison to the case where Turkey has domestic abatement efforts, it still prefers bilateral trading as it increases economic well being compared to the case where Turkey does not abate. However, under 30\% cutback, Turkey has critical output losses under bilateral trading due to high abatement burden on the EU. On the other hand, the EU favors bilateral trading as it passes some of its abatement burden to Turkey.

The following pages of the paper are organized as follows. In Section 2, we provide key environmental and economic data to portray Turkey's standing in comparison to the EU countries. In Section 3, the model structure and calibration strategy are laid out, together with the forward calibration procedure used in comparative static analysis. In Section 4, we describe the scenario runs and discuss the computational results. Section 5 summarizes our findings and concludes.

\section{Key environmental and economic indicators}

Over the period between 1990 and 2009, Turkey's GDP has shown a growing, yet highly volatile trend with a cumulative expansion of $92 \%$. Within the same period, Turkey has also experienced a rapid increase in its total primary energy supply (TPES). Table 1 reports this cumulative increase as $85.1 \%$.

Data supplied by the IEA (2011a) and OECD (2011) reveal that total primary energy supply of Turkey highly depends on coal and peat with $32 \%$, on natural gas with $30 \%$, and on crude oil and oil products with $27 \%$. The composition of TPES has been more stable since 2005, and yet, the share of renewable resources remains fairly low, around $4 \%$ for hydro, $5 \%$ for biofuels, and $2 \%$ for geothermal and solar resources. As coal, peat, oil and natural gas

Table 1

Key indicators of Turkey.

Source: IEA (2011a).

\begin{tabular}{|c|c|c|c|c|c|c|c|c|}
\hline & 1990 & 1995 & 2000 & 2005 & 2007 & 2008 & 2009 & Change 90-09 (\%) \\
\hline $\mathrm{CO}_{2}\left(\mathrm{Mt} \mathrm{of} \mathrm{CO}_{2}\right.$ ) & 126.91 & 152.66 & 200.56 & 216.36 & 265 & 263.53 & 256.31 & 102.00 \\
\hline TPES (Mtoe) & 52.76 & 61.55 & 76.35 & 84.38 & 100.01 & 98.5 & 97.66 & 85.10 \\
\hline GDP PPP (billion 2000 USD) & 411.06 & 481.43 & 589.24 & 736.17 & 823.66 & 829.09 & 789.08 & 92 \\
\hline Population (millions) & 55.12 & 59.76 & 64.26 & 68.58 & 70.26 & 71.08 & 71.9 & 30.40 \\
\hline $\mathrm{CO}_{2} / \mathrm{TPES}\left(\mathrm{t} \mathrm{CO}_{2}\right.$ per TJ) & 57.5 & 59.2 & 62.7 & 61.2 & 63.3 & 63.9 & 62.7 & 9.10 \\
\hline $\mathrm{CO}_{2} /$ GDP PPP (kg CO 2 per 2000 USD) & 0.31 & 0.32 & 0.34 & 0.29 & 0.32 & 0.32 & 0.32 & 5.20 \\
\hline $\mathrm{CO}_{2} /$ population ( $\mathrm{CO}_{2}$ per capita) & 2.3 & 2.55 & 3.12 & 3.15 & 3.77 & 3.71 & 3.57 & 54.80 \\
\hline
\end{tabular}


Table 2

Key indicators of the European Union.

Source: IEA (2011a).

\begin{tabular}{|c|c|c|c|c|c|c|c|c|}
\hline EU & 1990 & 1995 & 2000 & 2005 & 2007 & 2008 & 2009 & Change 90-09 (\%) \\
\hline $\mathrm{CO}_{2}\left(\mathrm{Mt}\right.$ of $\mathrm{CO}_{2}$ ) & 4051.9 & 3847.5 & 3831.2 & 3978.9 & 3941.9 & 3868.2 & 3576.8 & -11.7 \\
\hline TPES (Mtoe) & 1348.5 & 1406.2 & 1487 & 1565.2 & 1538.6 & 1536.4 & 1459.1 & 8.2 \\
\hline GDP PPP (billion 2000 USD) & 8556.4 & 9163.0 & 10591.8 & 11667.3 & 12445.5 & 12537.9 & 12007.6 & 40.2 \\
\hline Population (millions) & 472.9 & 478.7 & 482.9 & 492.1 & 496.4 & 498.7 & 500.4 & 5.8 \\
\hline $\mathrm{CO}_{2} / \mathrm{TPES}\left(\mathrm{t} \mathrm{CO}_{2}\right.$ per $\left.\mathrm{TJ}\right)$ & 59.1 & 56.1 & 54.3 & 53.4 & 53.6 & 52.8 & 51.6 & -12.8 \\
\hline $\mathrm{CO}_{2} / \mathrm{GDP}$ PPP (kg CO $\mathrm{CO}_{2}$ per 2000 USD) & 0.47 & 0.42 & 0.36 & 0.34 & 0.32 & 0.31 & 0.3 & -37.0 \\
\hline $\mathrm{CO}_{2} /$ population ( $\mathrm{CO}_{2}$ per capita) & 8.57 & 8.04 & 7.93 & 8.09 & 7.94 & 7.76 & 7.15 & -16.6 \\
\hline
\end{tabular}

are energy sources that are rich in carbon contents, it is not surprising to see the highly significant rise in Turkey's $\mathrm{CO}_{2}$ emissions between 1990 and 2009. Turkey's $\mathrm{CO}_{2}$ emissions increase from $126.91 \mathrm{Mt} \mathrm{CO}_{2}$ in 1990 to $256.31 \mathrm{Mt} \mathrm{CO}_{2}$ in 2009 , corresponding to a cumulative $102 \%$ rise. Within the same period the European Union experienced a decline of $11.7 \%$ in its total emission level, despite the $40.2 \%$ cumulative expansion in its GDP (Table 2).

By 2009, with per capita $\mathrm{CO}_{2}$ emissions of 3.57 tones, Turkey lies below the EU average of 7.15 tones. However, it is crucial to note the difference in the movements of per capita $\mathrm{CO}_{2}$ emissions. While Turkey has been experiencing $54.8 \%$ growth in its per capita $\mathrm{CO}_{2}$ emissions between 1990 and 2009, the EU experienced a successful decline in its per capita $\mathrm{CO}_{2}$ emissions by around $16.6 \%$.

Turkey's $\mathrm{CO}_{2}$ emissions per US\$ GDP was realized as 0.32 for 2009 , which is slightly higher than the EU ratio of 0.30 . This seems to be the constant trend since 2005. Just like the trend in per capita $\mathrm{CO}_{2}$ emissions, between 1990 and 2009, $\mathrm{CO}_{2}$ emissions per US\$ GDP also show an increase around 5.2\% in Turkey, and a 37\% decrease in the EU countries.

The differences in the above findings are mainly due to the differences in energy policies. It is clear that Turkey is experiencing highly emission intensive growth. IMF (2012) projects the annual growth rate of Turkish economy for the period between 2012 and 2017 as 3.7\% on average, while IEA (2011b) projects it as $4.0 \%$ on average. Therefore, in the long run, it is inevitable that Turkey will face rapid increase in its $\mathrm{CO}_{2}$ emissions along with the challenge of stabilizing its $\mathrm{CO}_{2}$ emissions.

On the contrary, the EU countries pursue energy policies that are more reliant on less emission intensive inputs. In addition to renewable energy promotion and energy efficiency improvement policies, the EU has implemented a wide use of permit trading to increase the cost efficiency of its climate change mitigation policies and also to generate revenue for fostering economic growth in the long run.

The amount of allowances traded in the EU ETS has been steadily increasing since 2005. In 2010, the amount is recorded as $6789 \mathrm{Mt} \mathrm{CO}$ equiv. of allowances at a market value of $\$ 134$ billion. In 2011, the number of traded allowances increased to $7853 \mathrm{Mt}$ $\mathrm{CO}_{2}$ equiv. with a market value of $\$ 148$ billion (World Bank, 2012). The carbon price in the second phase has been relatively more stable. The allowances were traded at $€ 25 / \mathrm{tCO}_{2}$ for much of 2008 , and in a range between $€ 13 / \mathrm{tCO}_{2}$ and $€ 17 / \mathrm{tCO}_{2}$ in the period between 2009 and 2011 (World Bank, 2012). Starting with 2012, the carbon price has reached to very low levels below $€ 10 / \mathrm{tCO}_{2}$, to around $€ 6 / \mathrm{tCO}_{2}$ (European Commission, 2012). This decrease is due to the growing surplus of allowances, which mainly stems from the great recession depressing emissions more than the anticipated levels and the expansion in the use of renewable technologies along with the increased availability of offset credits. As the surplus is anticipated to persist for most of the third phase, the Commission has launched a debate on some structural changes for the proper functioning of the EU ETS (European
Commission, 2012). Increasing the EU's emission reduction target for 2020 to $30 \%$ below the 1990 levels, bringing more sectors into the EU ETS, limiting the use of offset credits and introducing the use of cost-containment mechanisms have currently been debated.

\section{The analytical framework}

\subsection{Model structure and base year calibration}

In order to assess the economic impacts of Turkey's abatement policies, an applied general equilibrium model of commodity and permit trading is used, which is structurally comparable to the model used in (Böhringer and Rutherford, 2010). The model has a multi-region and multi-sector setting which builds up on the GTAP 7 data set representing the world economy at a global level for the reference year, 2004 (Badri and Walmsley, 2008). Akin Olcum (2012) gives a more detailed algebraic exposition of the model structure.

For the specific requirements of the current policy analysis, we aggregate the GTAP 7 data base into a more compact dataset. The energy goods specified are coal, crude oil, natural gas, refined oil products and electricity. These are the main driving forces behind $\mathrm{CO}_{2}$ emissions created through economic activities. In any abatement policy analysis, the $\mathrm{CO}_{2}$ intensity of sectors together with the technological possibilities of substitution between energy goods, are crucial in determining the magnitude of abatement and welfare changes. Taking into account all these, energy goods are identified and treated separately. Consequently, the energy intensive sectors are featured as: chemical industry, non-metallic minerals, iron and steel industry, non-ferrous metals, mining, paper-pulp-print and transport sectors. The remaining sectors are all other manufacturing industries, together with the "other economy".

Regarding regional disaggregation, Turkey is treated separately, while 27 European Union countries are all involved in the "EU" aggregate. All other regions are aggregated within the region "Rest of the World".

All markets are assumed to be perfectly competitive. There is a single representative agent in each economy who owns the primary factors of production, i.e. capital, labor and resources. Labor and capital are assumed to be mobile across sectors within regions but internationally immobile. Resource inputs are sectorspecific. All production factors are supplied inelastically in the factor markets.

Production activity is captured via nested constant elasticity of substitution (CES) functions, while technologies of extractive and non-extractive industries are modeled separately. For the nonextractive production technologies, energy goods, non-energy goods and factor inputs are all aggregated within separate CES nests. At the top level, these aggregates again trade off with each other, subject to a certain elasticity of substitution. Resource 
abundant extractive industries combine the sector specific natural resources and an aggregate of all other inputs at the top level using a CES function. This specification acts as a capacity constraint on the supply of the extractive industries. The other inputs are a Leontief composite of materials and the primary factor value added aggregate. Producers pay value added taxes over factor inputs, sales taxes over intermediate inputs, and production taxes.

Imperfectly competitive foreign demand approach of product heterogeneity is used to model bilateral trade flows in the model (Armington, 1969). All intermediate and final goods in the commodity markets are represented as Armingtonian composite goods, which are "produced" via imperfectly substituting domestic goods and imports. These activities are modeled via CES functions that aggregate domestic outputs with import composites of the same variety of the good, subject to a given elasticity of substitution. Export activities are also modeled subject to imperfect transformability between exports and domestic sales, which are expressed by constant elasticity of transformation (CET) functions. Each bilateral commodity trade flow is also subject to certain trade margin flows in fixed proportions. For each region, the financing of the current account deficit/surplus is exogenously set at base year values.

In the model formulation, there is not an explicit government unit. The representative agent of each region acts both as a household unit and also as a governmental unit. Therefore, all tax revenues accrue to the representative agent. Consumption demand of the representative agent is modeled via two-level nested CES functions. At the top nest, energy and non energy composites trade off, while at the lower level, within separate nests, energy goods and non-energy goods trade off with the same type of good. Demand for investment good and demand for public provision are set exogenously at their base year levels. Hence, savings adjust endogenously.

The underlying reason for using this Kaldorian closure combining fixed foreign savings, fixed real investment and fixed real public consumption is to be able to explore the pure welfare effects of alternative policies in a comparative static general equilibrium framework. Using the Kaldorian closure minimizes the risk of biased welfare effects that would otherwise occur with endogenous foreign savings and real investment in the upcoming periods. In addition to that, since the model does not capture the direct effects of public provision on household's welfare, it is also preferred to use government consumption as fixed exogenously.

In order to include a market for trading permits, the national (regional) commodity trade markets are further expanded by integrating emission creation mechanism and giving incentives to trade permits. In the model, trading is only allowed for $\mathrm{CO}_{2}$ permits. In each regional economy, $\mathrm{CO}_{2}$ emissions are created by the use of fossil fuels, i.e. coal, oil and natural gas. The $\mathrm{CO}_{2}$ emitters that are required to hold allowances in equal amounts to their total emissions are taken as the downstream entities, i.e. users of dirty inputs. Hence, the production and consumption units using fossil fuels are specified as the permit demanders, while the representative agent is the unit supplying the permits to the $\mathrm{CO}_{2}$ emitters. The users of fossil fuels are subject to certain $\mathrm{CO}_{2}$ quotas which are fixed exogenously. Allowances, in equal amounts to the target $\mathrm{CO}_{2}$ emission levels, are supplied by the representative agent. Auctioning is used for allocating allowances to the emitters. In a theoretical paper, Montgomery (1972) proves that the equilibrium allocation of permits, along with their market-determined prices and aggregate costs of abatement are independent of the initial allocation of permits. In what follows, under assumptions of perfectly competitive markets and zero transaction costs, we numerically derive the permit price as the respective shadow price of the aggregate $\mathrm{CO}_{2}$ quota. The corresponding price is the price at which marginal abatement costs are equalized across all regions and sectors involved in permit trading. The equilibrium allocation of permits and aggregate abatement costs are derived accordingly.

In the model, permit trading is modeled both at the international and regional levels. That is to say it is possible for regions to run their regional cap-and-trade systems simultaneously integrating with the international cap-and-trade systems. Furthermore, the model also allows for market segmentation, in the sense that certain sectors are allowed to trade permits with each other. The decision regarding the grouping of sectors is on each region's own initiative.

\subsection{Forward calibration}

For any given target year, the corresponding business-as-usual $(B A U)$ scenario is calibrated on top of the base year economies in 2004. In formulating the $B A U$ scenario, we use the forward calibration techniques as implemented in Böhringer and Rutherford (2010). While doing so, we made use of regional projections on GDP growth rates, population growth rates, energy demands, and $\mathrm{CO}_{2}$ emissions for the target year. The projection data from the US Energy Information Agency-International Energy Outlook (IEO)-are used for the BAU calibration of the aggregate economies in the model, i.e. the EU and the ROW (EIA, 2010). GTAP7inGAMS routines are used in aggregating the IEO country groupings in line with the region profile used in this study (Rutherford, 2011). Since the IEO data set loses its accuracy in more disaggregated forms of some regional compositions, it is further complemented with more detailed information from the International Energy Agency (IEA) for the $B A U$ calibration of the Turkish economy (IEA, 2011b).

\section{Policy scenarios and analysis}

In this section, we now turn to the design of environmental and economic policy framework in which we will investigate the potential welfare effects of Turkey's application of various permit trading schemes. The target year is set as 2020 and the main focus is on the use of market-based environmental policies that Turkey and the EU are committed to apply within this period. In this regard, policies promoting the use of renewable energy and offset credits are not explicitly modeled and analyzed. Nevertheless, non-price driven improvements in the energy intensities of the respective economies are assumed to take place and represented by the use of autonomous energy efficiency indices (Lee et al., 1994; Paltsev et al., 2005).

As a first step in our policy analysis, the EU is assumed to stick to the emission reduction target of 20\% relative to the 1990 levels, which is set by the current EU 20-20-20 targets. This total target is expected to be achieved through emission reduction levels of $21 \%$ for the EU ETS sectors and 10\% for non-ETS sectors, compared to their 2005 levels (European Commission, 2008). In the second part, we investigate the economic impacts in case of an increase in the EU's emission reduction target to 30\% below 1990 levels, which is currently under consideration for sustaining the proper functioning of the EU ETS during the third phase (European Commission, 2012).

Since Turkey has not yet engaged officially in any kind of legal sanctions for $\mathrm{CO}_{2}$ emissions, the total emission cutback ratio and its distribution across sectors are still not clear. Additionally, the sectors which are planned to trade permits and the ones which are likely to exercise other market-based policies are not specified, either. Therefore, in formulating Turkey's policy scenarios, we stick to signals of political realism and chose to stay in line with the European criteria. 
Table 3

Emission reduction requirements for the European Union. Source: Authors' computations.

\begin{tabular}{|c|c|c|c|c|}
\hline & \multicolumn{2}{|c|}{ Under $20 \%$ cutback } & \multicolumn{2}{|c|}{ Under $\mathbf{3 0 \%}$ cutback } \\
\hline & $\begin{array}{l}\text { Nominal } \\
\text { target }\end{array}$ & $\begin{array}{l}\text { Effective } \\
\text { target }\end{array}$ & $\begin{array}{l}\text { Nominal } \\
\text { target }\end{array}$ & $\begin{array}{l}\text { Effective } \\
\text { target }\end{array}$ \\
\hline ETS Sectors & 21 & 22.5 & 30.9 & 32.3 \\
\hline $\begin{array}{c}\text { Non ETS } \\
\text { sectors }\end{array}$ & 10 & 8.7 & 21.3 & 20.1 \\
\hline Total & 15 & 15.1 & 25.7 & 25.7 \\
\hline
\end{tabular}

\subsection{Policy scenarios}

In all of the counterfactual simulations, the sectors involved in the EU ETS are specified as electricity, refined oil, chemical, iron and steel, non-metallic minerals, non-ferrous metal and paperpulp-print industries. Table 3 summarizes the nominal reduction targets of the EU stated relative to 2005 levels, and also the effective reduction targets, which are expressed relative to 2020 levels. ${ }^{1}$

For the EU, the nominal reduction rates are not translated into significantly higher effective reduction rates. There is even a decrease in the cutback ratio of the non ETS sectors. This is mainly due to low economic growth level, which is projected as $1.8 \%$ annual on average between 2004 and 2020, and high improvement percentages in energy efficiency levels, as given in the IEO 2010 projections.

In terms of market-based environmental policies, we simulate and analyze the following strategies that Turkey can choose to apply during the post-Kyoto period:

- NOACT: Turkey does not take any abatement action.

- C_rETS: This scenario simulates a comprehensive permit trading scheme, where Turkey sets binding $\mathrm{CO}_{2}$ emission quota covering all $\mathrm{CO}_{2}$ emitting sectors. Indeed, under the current model formulation, the $C_{-}$rETS scenario also corresponds to a uniform national $\mathrm{CO}_{2}$ tax policy.

- S_rETS: In a segmented emission trading scheme, Turkey is assumed to segment its permit market into two main parts, i.e. ETS sectors and non ETS sectors. ${ }^{2}$ The respective emission reduction targets for these sector groups are set in proportion to their 2004 emission levels. While the ETS sectors are assumed to trade permits with each other, the non ETS sectors are subject to separate abatement policies.

- EU_ETS: This scenario extends the S_rETS scenario, in a way that the Turkish ETS sectors are assumed to trade permits within the EU ETS and the non ETS sectors are subject to other domestic abatement policies. The emission reduction targets for the ETS and non ETS sectors are set in proportion to their 2004 levels.

Among the possible cutback ratios that Turkey is likely to apply by 2020 , we simulate $10 \%, 15 \%$, and $20 \%$ reduction rates, relative to 2004 levels. Table 4 reports the nominal and effective reduction targets with respect to 2004 and 2020, respectively. As opposed to the EU, Turkey's total $\mathrm{CO}_{2}$ emission level increases significantly,

\footnotetext{
${ }^{1}$ In case of an increase in the EU's emission reduction target to $30 \%$, the distribution of allowances across the ETS and non ETS sectors is not officially set, yet. Hence, we assume that the existing distribution will be preserved under the $30 \%$ cutback ratio, as well.

${ }^{2}$ ETS sectors are assumed to be the same with the European ETS sectors, i.e. electricity, refined oil, chemical, iron and steel, non-metallic minerals, non-ferrous metals and paper-pulp-print industries.
}

Table 4

Emission reduction requirements for Turkey. Source: Authors' computations.

\begin{tabular}{llllllll}
\hline & \multicolumn{3}{c}{ Nominal targets } & & & \multicolumn{3}{c}{ Effective targets } \\
\cline { 2 - 4 } \cline { 7 - 8 } & $\mathbf{1 0 \%}$ & $\mathbf{1 5 \%}$ & $\mathbf{2 0 \%}$ & & $\mathbf{1 0 \%}$ & $\mathbf{1 5 \%}$ & $\mathbf{2 0 \%}$ \\
\hline ETS Sectors & 10 & 15 & 20 & & 24.2 & 28.4 & 32.6 \\
Non ETS sectors & 10 & 15 & 20 & & 8.8 & 13.8 & 18.9 \\
Total & 10 & 15 & 20 & & 16.9 & 21.5 & 26.1 \\
\hline
\end{tabular}

resulting in higher effective reduction requirements with respect to the $B A U$ emission levels in 2020. If we take into account high economic growth and low energy efficiency improvement projections for Turkey, according to the IEA (2011b), the high differentials between nominal and effective reduction rates should not be surprising.

\subsection{Policy analysis under the current EU 20-20-20 targets}

In this first part of our analysis, we investigate the economic impacts when the EU applies the emission reduction target of $20 \%$.

Under the NOACT scenario, the European production sectors experience a considerable rise in their marginal costs of production. The permit price in the EU ETS realizes as $\$ 17.73 / \mathrm{tCO}_{2}$, while the marginal abatement cost (MAC) of the non ETS sectors realizes as $\$ 84.19 / \mathrm{tCO}_{2}$ (Table 5). This increase further results in loss of competitiveness with consequent in the production levels across the European industries. The decrease in the EU's aggregate economic activity is measured as $0.24 \%$ compared to the $B A U$ scenario. Following the contraction in its economy, the EU suffers from welfare losses. As Fig. 1 gives, the EU's welfare loss under the NOACT scenario is $0.38 \%$ relative to the BAU level. ${ }^{3}$

Increasing and diverging marginal costs between the European ETS and non ETS sectors under the EU 20-20-20 targets, is also evident in other studies. For 2020, using Gemini-E3, Bernard and Vielle (2009) calculate the MAC of the ETS sectors and non ETS sectors as $72 € / \mathrm{tCO}_{2}$ and $194 € / \mathrm{tCO}_{2}$, respectively. They state that the higher MACs for the European sectors lead to higher welfare loss for the EU, which is calculated as $1 \%$ with respect to the BAU scenario. ${ }^{4}$ In their applied general equilibrium analysis, Böhringer et al. (2009) find that, under $20 \%$ reduction target, the EU suffers from welfare losses around $0.3 \%$ by 2020 in comparison to the BAU path (See footnote 4). The MACs are considerably lower than the ones from the Gemini-E3 model, i.e. $36 € / \mathrm{tCO}_{2}$ for the ETS sectors and $104 € / \mathrm{tCO}_{2}$ for the non ETS sectors. The differences in the MACs from these existing studies and the ones in our study should be mainly attributed to the differences in the GDP and energy efficiency growth projections, together with forecasts for energy prices.

Abatement policies in the EU affect not only the domestic, but also the international markets. As being one of the three biggest users and importers of energy goods in the global economy, the decrease in the EU's import demand for primary energy carriers causes price adjustments both in the domestic and the world markets. The cutback in international fossil fuel demand immediately reflects itself as depressed international fuel prices. While the price of coal and natural gas decrease around $2 \%$ relative to the $B A U$ scenario, the decrease in the price of refined and crude oil is around $0.8 \%$. As narrated in similar occasions of Bohringer and

\footnotetext{
${ }^{3}$ Throughout this study, the change in economic welfare is measured as Hicksian equivalent variation. This corresponds to the amount of income that is necessary to compensate the representative agent for welfare changes, which occurs as a result of economic policies.

${ }^{4}$ The change in welfare is given in Hicksian Equivalent Variation.
} 
Table 5

MACs in the EU under the current EU 20-20-20 targets ( $\$$ per ton of $\mathrm{CO}_{2}$ ). Source: Authors' computations.

\begin{tabular}{|c|c|c|c|c|c|c|c|c|c|c|}
\hline & \multirow[t]{2}{*}{ NOACT } & \multicolumn{3}{|c|}{ C_rETS } & \multicolumn{3}{|c|}{ S_rETS } & \multicolumn{3}{|c|}{ EU_ETS } \\
\hline & & $10 \%$ & $15 \%$ & $20 \%$ & $10 \%$ & $15 \%$ & $20 \%$ & $10 \%$ & $15 \%$ & $20 \%$ \\
\hline ETS Sectors & 17.73 & 17.76 & 17.77 & 17.78 & 17.76 & 17.77 & 17.78 & 17.9 & 18.24 & 18.59 \\
\hline Non ETS sectors & 84.19 & 84.24 & 84.26 & 84.3 & 84.24 & 84.29 & 84.37 & 84.23 & 84.27 & 84.33 \\
\hline
\end{tabular}

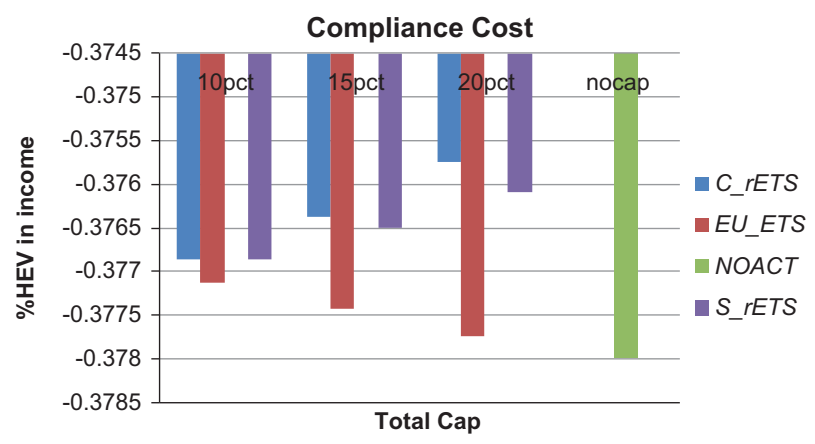

Fig. 1. Welfare effects for the EU under the current EU 20-20-20 targets.

Rutherford (2002) and Babiker et al. (2004), these chain effects can have negative or positive spillover effects on other non-abating regions. As a fuel importer, Turkey benefits from decreasing fuel price levels, and increases the use and imports of fossil fuels (Table 11). Turkey's coal imports increases by $2.01 \%$, crude oil imports rises by $0.62 \%$, while imports of natural gas and oil increases by $0.62 \%$ and $0.36 \%$, respectively, compared to their $B A U$ levels. Due to cheaper primary energy imports, the secondary energy sectors, i.e. refined oil and electricity, increase their scales of production (Table 9). Thus, electricity prices decrease in the domestic market.

Consequently, cheaper energy prices ought to cause positive scale effects on other non-energy sectors, as well. However, nonenergy sectors are exposed to various general equilibrium adjustments mostly propelled by imperfect substitution and product heterogeneity of traded goods. Depending on the interdependence between regions via international trade, higher prices of exports, together with decreasing import demand in the abating regions may lead to negative scale effects on the production sectors in non-abating trade partners. In Turkey's case, while transport services, chemical and non-ferrous metals industries increase their scales of production, export oriented industries, most of which are the manufacturing industries, including iron and steel industry, non-metallic minerals and textile industry, are all exposed to negative scale effects (Table 9). The effect of decreasing import demand from the EU and shifting trade patterns gradually undermine the positive scale effect stemming from depressed international fuel prices.

Despite the negative scale effects on export oriented industries, the overall economic activity in Turkey increases compared to the BAU scenario. Hence, Turkey achieves net welfare gains under the NOACT scenario (Fig. 2).

When Turkey has comprehensive permit trading, there realizes a unique permit price in Turkey, at the rate $\$ 19.9 / \mathrm{tCO}_{2}$ under $10 \%$ cap. This rate increases in a nonlinear fashion as the cutback ratio increases. Table 6 gives the permit price levels under $15 \%$ and $20 \%$ quotas as $\$ 29.74$ and $\$ 43.25$, respectively. In comparison to (Aydin and Acar, 2010), our MAC curves are found considerably steeper. In their analysis when Turkey applies $45 \%$ cutback with respect to 2005 , the permit price has been found as $\$ 45.92$, which, in contrast, is close to the price level under 20\% cap with our

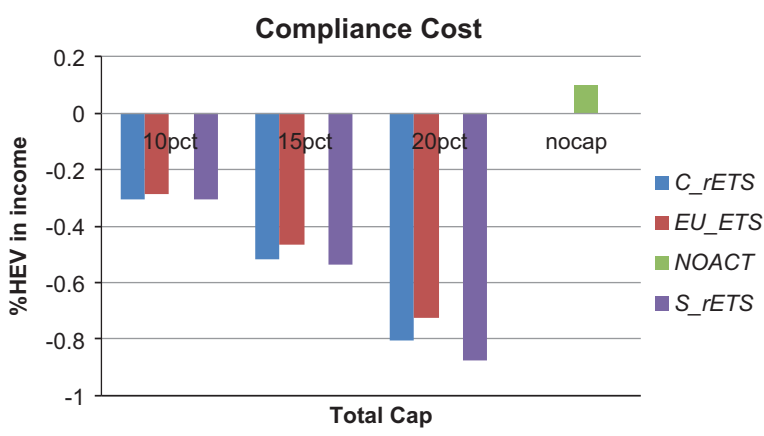

Fig. 2. Welfare effects for Turkey under the current EU 20-20-20 targets.

modeling framework. Clearly, these differences are due both to the differences of the methodology and the adjustment mechanisms therein modeled.

As Table 10 shows, most of the abatement is undertaken by electricity, chemicals, iron and steel, non-metallic minerals, manufacturing and other economy sectors. Additionally, due to these negative scale effects on the economy, the other energy sectors, i.e. coal, natural gas and oil face declines in their real output levels relative to the BAU levels (see Tables 9 and 10 below). The contraction in these sectors continues to grow as the cap increases. Hence, Turkey's aggregate economic activity under the C_rETS scenario falls behind the levels under the NOACT and $B A U$ scenarios. As Fig. 2 shows, this causes welfare losses for Turkey, which is quantified as $0.30 \%$ under $10 \%$ quota, relative to the BAU level. The welfare loss further increases to $0.80 \%$ under the $20 \%$ quota. In sum, the higher the cutback requirement, the higher becomes the welfare loss.

The EU economy is affected by Turkey's abatement policies via two separate channels. Firstly, the MACs of the European ETS and non ETS sectors are subject to changes depending on Turkey's abatement actions. Imperfect substitution in international trade (the Armingtonian composite commodity structure) leads Turkey to pass on some of its cost burden to its trading partners including the EU. The other channel affecting the EU economy is the change in competitiveness in both domestic and international markets relative to the loss of competitiveness of the Turkish industries. The ability of the EU to turn Turkey's disadvantage in international competitiveness into gains is very much dependent on the European production technologies and also on the degree of openness to bilateral trade.

Under the C_rETS scenario, the permit price in the EU ETS slightly increases from $\$ 17.73 / \mathrm{tCO}_{2}$ to $\$ 17.76, \$ 17.77, \$ 17.78$ under $10 \%, 15 \%$ and $20 \%$ quota, respectively. It is mainly the foregone opportunity of importing cheaper secondary energy carriers from Turkey, which underlies the increase in the MACs of the European sectors. The price level in the European non ETS market increases from $\$ 84.19 / \mathrm{tCO}_{2}$ to $\$ 84.24$ under the $10 \%$ quota and it further reaches to $\$ 84.3$, under the $20 \%$ quota.

Despite increasing marginal costs, the EU economy undergoes a positive scale effect, which stems from increasing competitiveness 
Table 6

MACs in Turkey under the current EU 20-20-20 targets (\$ per ton of $\mathrm{CO}_{2}$ ).

Source: Authors' computations.

\begin{tabular}{|c|c|c|c|c|c|c|c|c|c|c|}
\hline & \multirow[t]{2}{*}{ NOACT } & \multicolumn{3}{|c|}{ C_rETS } & \multicolumn{3}{|c|}{ S_rETS } & \multicolumn{3}{|c|}{ EU_ETS } \\
\hline & & $10 \%$ & $15 \%$ & $20 \%$ & $10 \%$ & $15 \%$ & $20 \%$ & $10 \%$ & $15 \%$ & $20 \%$ \\
\hline ETS Sectors & - & 19.9 & 29.74 & 43.25 & 20.09 & 26.63 & 34.91 & 17.9 & 18.24 & 18.59 \\
\hline Non ETS sectors & - & 19.9 & 29.74 & 43.25 & 19.42 & 38.39 & 67.55 & 19.38 & 38.27 & 67.46 \\
\hline
\end{tabular}

Table 7

MACs in the EU under the revised EU 20-20-20 targets ( $\$$ per ton of $\mathrm{CO}_{2}$ ).

Source: Authors' computations.

\begin{tabular}{|c|c|c|c|c|c|c|c|c|c|c|}
\hline & \multirow[t]{2}{*}{ NOACT } & \multicolumn{3}{|l|}{ C_rETS } & \multicolumn{3}{|l|}{ S_rETS } & \multicolumn{3}{|l|}{ EU_ETS } \\
\hline & & $10 \%$ & $15 \%$ & $20 \%$ & $10 \%$ & $15 \%$ & $20 \%$ & $10 \%$ & $15 \%$ & $20 \%$ \\
\hline ETS Sectors & 34.12 & 34.16 & 34.17 & 34.19 & 34.16 & 34.17 & 34.18 & 33.06 & 33.64 & 34.23 \\
\hline Non ETS sectors & 266.46 & 266.52 & 266.56 & 266.60 & 266.53 & 266.61 & 266.73 & 266.59 & 266.64 & 266.73 \\
\hline
\end{tabular}

Table 8

MACs in Turkey under the revised EU 20-20-20 targets (\$ per ton of $\mathrm{CO}_{2}$ ).

Source: Authors' computations.

\begin{tabular}{|c|c|c|c|c|c|c|c|c|c|c|}
\hline & \multirow[t]{2}{*}{ NOACT } & \multicolumn{3}{|c|}{ C_rETS } & \multicolumn{3}{|c|}{ S_rETS } & \multicolumn{3}{|c|}{ EU_ETS } \\
\hline & & $10 \%$ & $15 \%$ & $20 \%$ & $10 \%$ & $15 \%$ & $20 \%$ & $10 \%$ & $15 \%$ & $20 \%$ \\
\hline ETS Sectors & - & 20.69 & 30.81 & 44.72 & 20.1 & 26.67 & 34.98 & 33.06 & 33.64 & 34.23 \\
\hline Non ETS sectors & - & 20.69 & 30.81 & 44.72 & 22.25 & 42.67 & 73.71 & 22.54 & 42.79 & 73.7 \\
\hline
\end{tabular}

Table 9

Sectorial production, Turkey (billion 2004 USD).

Source: Authors' computations.

\begin{tabular}{|c|c|c|c|c|c|c|c|c|c|c|c|}
\hline \multicolumn{3}{|l|}{ Turkey } & \multicolumn{3}{|l|}{$10 \%$} & \multicolumn{3}{|l|}{$15 \%$} & \multicolumn{3}{|l|}{$20 \%$} \\
\hline Sectors $^{\mathrm{a}}$ & 2020 & NOACT & C_rETS & S_rETS & EU_ETS & C_rETS & S_rETS & EU_ETS & C_rETS & S_rETS & EU_ETS \\
\hline oil & 8.027 & 8.072 & 7.939 & 7.941 & 7.946 & 7.875 & 7.846 & 7.865 & 7.789 & 7.709 & 7.745 \\
\hline gas & 0.040 & 0.040 & 0.039 & 0.039 & 0.039 & 0.039 & 0.039 & 0.039 & 0.038 & 0.039 & 0.039 \\
\hline omn & 4.564 & 4.559 & 4.523 & 4.522 & 4.526 & 4.508 & 4.514 & 4.529 & 4.490 & 4.505 & 4.532 \\
\hline tex & 70.958 & 70.467 & 70.299 & 70.302 & 70.320 & 70.237 & 70.199 & 70.264 & 70.159 & 70.067 & 70.180 \\
\hline ppp & 13.616 & 13.599 & 13.533 & 13.532 & 13.540 & 13.504 & 13.518 & 13.547 & 13.467 & 13.502 & 13.558 \\
\hline crp & 24.426 & 24.450 & 23.732 & 23.725 & 23.801 & 23.424 & 23.532 & 23.815 & 23.032 & 23.305 & 23.838 \\
\hline $\mathrm{nmm}$ & 18.091 & 18.064 & 17.783 & 17.780 & 17.810 & 17.673 & 17.718 & 17.826 & 17.540 & 17.650 & 17.850 \\
\hline i_s & 30.243 & 30.180 & 29.402 & 29.395 & 29.478 & 29.084 & 29.198 & 29.506 & 28.688 & 28.975 & 29.550 \\
\hline $\mathrm{nfm}$ & 2.321 & 2.334 & 2.007 & 2.005 & 2.036 & 1.883 & 1.922 & 2.036 & 1.735 & 1.829 & 2.038 \\
\hline ele & 22.714 & 22.737 & 21.973 & 21.966 & 22.042 & 21.667 & 21.776 & 22.059 & 21.291 & 21.557 & 22.083 \\
\hline omf & 121.397 & 120.605 & 120.546 & 120.550 & 120.550 & 120.550 & 120.501 & 120.498 & 120.572 & 120.474 & 120.460 \\
\hline col & 1.036 & 1.024 & 0.795 & 0.795 & 0.807 & 0.740 & 0.742 & 0.781 & 0.688 & 0.694 & 0.759 \\
\hline cru & 0.397 & 0.396 & 0.395 & 0.395 & 0.395 & 0.394 & 0.394 & 0.395 & 0.394 & 0.393 & 0.394 \\
\hline $\operatorname{trn}$ & 94.515 & 95.527 & 95.300 & 95.315 & 95.288 & 95.162 & 94.909 & 94.813 & 94.960 & 94.271 & 94.091 \\
\hline aog & 536.849 & 536.573 & 536.703 & 536.702 & 536.681 & 536.716 & 536.728 & 536.657 & 536.717 & 536.753 & 536.638 \\
\hline
\end{tabular}

a Oil, refined oil products; gas, natural gas works; omn, mining; tex, textiles; ppp, paper and paper products; crp, chemicals; nmm, non-metallic minerals; i_s, iron and steel; nfm, non-ferrous metals; ele, electricity; omf, other manufacturing; col, coal; cru, crude oil; trn, transport; aog, all other goods.

of the European sectors in international markets. The positive scale effect on the EU economy becomes more significant as the Turkish industries lose more of their competitiveness in the international markets.

As summarized in Fig. 1, the positive scale effect on the European economy reflects itself as increases in the EU's economic welfare. Compared to the $B A U$ case, the EU still suffers from welfare loss, at a rate of around $0.377 \%$. However, the loss is strictly smaller than the one that the EU would suffer under the NOACT scenario. Hence, in relative terms, the EU has some welfare gains when Turkey applies abatement policies countrywide and this gain increases as Turkey applies stricter abatement targets.

Under the "partitioned permit trading scheme", the ex-ante distribution of allowances across the ETS and the non ETS sectors distorts the Turkish permit market. Fig. 3 gives the difference between the total allowances allocated to the ETS sectors under the $S_{-} r E T S$ and $C_{-} r E T S$ scenarios. Under the $C_{-} r E T S$ scenario, the final allocation of permits across the sectors corresponds to the efficient allocation. Hence, it is seen that, for the $10 \%$ cap, the ETS sectors are slightly under-allocated by $0.167 \mathrm{Mt}$ of $\mathrm{CO}_{2}$ under the 
Table 10

Sectorial emissions, Turkey (Mt of $\mathrm{CO}_{2}$ ).

Source: Authors' computations.

\begin{tabular}{|c|c|c|c|c|c|c|c|c|c|c|c|}
\hline \multirow{2}{*}{$\begin{array}{l}\text { Turkey } \\
\text { Sectors }^{a}\end{array}$} & \multirow[b]{2}{*}{2020} & \multirow[b]{2}{*}{ NOACT } & \multicolumn{3}{|l|}{$10 \%$} & \multicolumn{3}{|l|}{$15 \%$} & \multicolumn{3}{|l|}{$20 \%$} \\
\hline & & & $C_{-}$rETS & S_rETS & EU_ETS & $C_{-}$rETS & S_rETS & EU_ETS & C_rETS & S_rETS & EU_ETS \\
\hline oil & 0.166 & 0.167 & 0.152 & 0.152 & 0.153 & 0.145 & 0.146 & 0.151 & 0.137 & 0.139 & 0.149 \\
\hline gas & 0.000 & 0.000 & 0.000 & 0.000 & 0.000 & 0.000 & 0.000 & 0.000 & 0.000 & 0.000 & 0.000 \\
\hline omn & 0.370 & 0.371 & 0.270 & 0.272 & 0.272 & 0.245 & 0.227 & 0.227 & 0.220 & 0.191 & 0.190 \\
\hline tex & 2.197 & 2.192 & 1.912 & 1.917 & 1.916 & 1.831 & 1.764 & 1.759 & 1.745 & 1.613 & 1.604 \\
\hline ppp & 2.614 & 2.622 & 2.021 & 2.017 & 2.060 & 1.868 & 1.913 & 2.056 & 1.719 & 1.808 & 2.053 \\
\hline crp & 11.313 & 11.364 & 9.250 & 9.237 & 9.391 & 8.687 & 8.855 & 9.383 & 8.123 & 8.467 & 9.378 \\
\hline $\mathrm{nmm}$ & 12.447 & 12.496 & 8.775 & 8.753 & 9.015 & 7.829 & 8.106 & 8.995 & 6.918 & 7.461 & 8.977 \\
\hline i_s & 5.338 & 5.354 & 4.211 & 4.204 & 4.288 & 3.907 & 3.997 & 4.284 & 3.602 & 3.787 & 4.282 \\
\hline $\mathrm{nfm}$ & 2.318 & 2.339 & 1.717 & 1.713 & 1.761 & 1.539 & 1.593 & 1.759 & 1.354 & 1.467 & 1.758 \\
\hline ele & 81.690 & 82.054 & 61.927 & 61.810 & 63.202 & 56.920 & 58.394 & 63.114 & 52.092 & 54.991 & 63.034 \\
\hline omf & 4.569 & 4.565 & 3.252 & 3.273 & 3.270 & 2.922 & 2.687 & 2.676 & 2.604 & 2.206 & 2.189 \\
\hline col & 0.001 & 0.001 & 0.001 & 0.001 & 0.001 & 0.001 & 0.001 & 0.001 & 0.000 & 0.000 & 0.001 \\
\hline cru & 0.000 & 0.000 & 0.000 & 0.000 & 0.000 & 0.000 & 0.000 & 0.000 & 0.000 & 0.000 & 0.000 \\
\hline $\operatorname{trn}$ & 28.895 & 29.253 & 28.773 & 28.786 & 28.783 & 28.539 & 28.326 & 28.317 & 28.224 & 27.653 & 27.635 \\
\hline aog & 26.198 & 26.310 & 21.310 & 21.389 & 21.374 & 19.985 & 19.025 & 18.974 & 18.676 & 16.953 & 16.953 \\
\hline
\end{tabular}

a Oil, refined oil products; gas, natural gas works; omn, mining; tex, textiles; ppp, paper and paper products; crp, chemicals; nmm, non-metallic minerals; i_s, iron and steel; nfm, non-ferrous metals; ele, electricity; omf, other manufacturing; col, coal; cru, crude oil; trn, transport; aog, all other goods.

Table 11

Change in fuel consumption in Turkey (relative to the BAU level).

Source: Authors' computations.

\begin{tabular}{|c|c|c|c|c|c|c|c|c|c|c|}
\hline \multicolumn{2}{|l|}{ Turkey } & \multicolumn{3}{|l|}{$10 \%$} & \multicolumn{3}{|l|}{$15 \%$} & \multicolumn{3}{|l|}{$20 \%$} \\
\hline Fossil fuel & NOACT & C_rETS & S_rETS & EU_ETS & C_rETS & S_rETS & EU_ETS & C_rETS & S_rETS & EU_ETS \\
\hline Oil & 0.546 & -1.206 & -1.184 & -1.120 & -2.054 & -2.440 & -2.197 & -3.191 & -4.245 & -3.785 \\
\hline Gas & 0.606 & -3.156 & -3.155 & -2.854 & -5.029 & -5.029 & -3.872 & -7.521 & -7.456 & -5.217 \\
\hline Coal & 0.492 & -30.512 & -30.527 & -28.942 & -38.106 & -37.852 & -32.542 & -45.259 & -44.621 & -35.710 \\
\hline
\end{tabular}

Total ETS Allowances

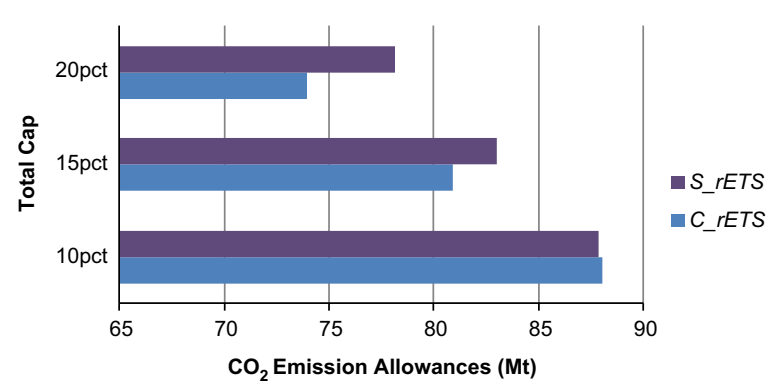

Fig. 3. Allowance allocation to the ETS sectors in Turkey.

S_rETS scenario. The ETS sectors are obliged to abate more than what they would abate under the comprehensive trading scheme. Following this, MAC of the ETS sectors increases to $\$ 20.09$ from $\$ 19.9 / \mathrm{tCO}_{2}$. As given in Fig. 4, the non ETS sectors are overallocated under the S_rETS scenario. Thus, MAC of the non ETS sectors becomes $\$ 19.42 / \mathrm{tCO}_{2}$. The abatement cost at the margin decreases compared to the $C_{-} r E T S$ case.

Under $15 \%$ and $20 \%$ caps, over allocation is observed in the ETS sectors, while the non ETS sectors are given less amounts of allowances in comparison to the efficient allocation. The efficiency loss arising from over-allocating the ETS sectors and underallocating the non ETS sectors is further reflected in the MACs. As Table 6 reports, the "allowance price" drops down to $\$ 26.63$ and $\$ 34.91$ in the ETS market under $15 \%$ and $20 \%$ quota, respectively. In the non ETS market, MAC increases to $\$ 38.39$ and $\$ 67.55$ under $15 \%$ and $20 \%$ quota, respectively.

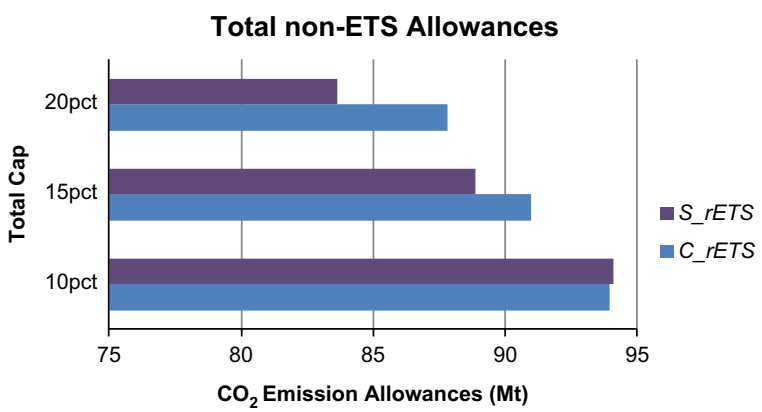

Fig. 4. Allowance allocation to the non-ETS sectors in Turkey.

Segmenting the permit market basically causes shifts in sharing the abatement cost burden across sectors. Under the 15\% and $20 \%$ caps, the ETS sectors shift some of their abatement duties to the non ETS sectors. In contrast, under the $10 \%$ cap, the ETS sectors are obliged to abate more, while the non ETS sectors are obliged to abate less. The distortion arising from ex-ante allocation of permits causes the Turkish economy to experience efficiency losses in meeting its total abatement objectives. The higher the cutback requirement, the higher is the cost burden on cleaner industries, relative to the cost burden on energy intensive sectors. The resulting high price differential between the MACs of the ETS and the non ETS sectors lead to production efficiency losses, which are further translated into losses in social welfare. As seen in Fig. 2 above, under the $10 \%$ quota, Turkey's economic loss is $0.30 \%$, which is almost the same as the one under the comprehensive trading scheme. This is due to the fact that the decrease of the cost burden on cleaner industries compensates for the increasing cost burden 
on energy industries as Turkey's sectors are highly dependent on energy imports. However, the economic loss increases to $0.54 \%$ and $0.88 \%$ under the $15 \%$ and $20 \%$ quotas, respectively. Hence, we conclude that in comparison to the comprehensive permit market, partitioned market structure results in more welfare loss.

In comparison to the NOACT scenario, the European Union is positively affected when Turkey applies permit trading in a partitioned market structure. Despite the increase in the MACs of the ETS and non ETS sectors, the European industries expand their market shares in the domestic and the Turkish markets. Hence, the overall economic activity in the EU increases. Furthermore, the EU benefits more as the cutback ratio that Turkey applies increases (Fig. 1).

In comparison with $C_{-} r E T S$ scenario, the EU's total economic activity level increases when Turkey applies 10\% cap. Taking into account the fact that MACs of European sectors do not change, it is clear that this increase is mainly due to the efficiency loss in the Turkish economy arising from market segmentation. In contrast, under $15 \%$ and $20 \%$ quota, the EU is negatively affected by interventions to the Turkish permit market. Total economic activity decreases below its base level under the $C_{-} r E T S$ scenario. This decrease in the total output is mainly due to the relative increase in the marginal production costs of the European sectors, accompanied with the decreasing market share of the Turkish domestic markets. Hence, as it is seen in Fig. 1, although the EU enjoys more welfare gains under the $S_{-} r E T S$ scenario, these gains are slightly smaller in comparison to the levels under the comprehensive permit trading.

When the Turkish and the European ETSs integrate, the permit price in the EU ETS increases from $\$ 17.73$ to $\$ 17.90$ under $10 \%$ quota, to $\$ 18.24$ under $15 \%$ quota and to $\$ 18.59$ under $20 \%$ quota. In comparison to the permit price levels prevailing in the regional ETSs, the Turkish ETS sectors face considerable decrease in the price level after integration. The price differential gets more significant as the total cap increases. It is also crucial to note that while permit price level in the regional ETSs are more volatile against changes in the emission caps, the price level in the EU ETS is less volatile.

As opposed to the Turkish ETS sectors, the European ETS sectors face higher permit price levels after integration. This increase is mainly because of the high level of MAC of the Turkish ETS sectors, which are summarized in Table 6. The differences between MACs provide Turkey additional incentives to buy permits in the market place instead of abating at home, while the European ETS sectors have an incentive to sell permits in exchange of decreasing their emission levels. Thus, in the EU ETS market, while the EU markets becomes a permit exporter, Turkey becomes a permit importer and shifts some of its abatement cost burden to the EU via permit trading. As Fig. 5 portrays, Turkey's total permit

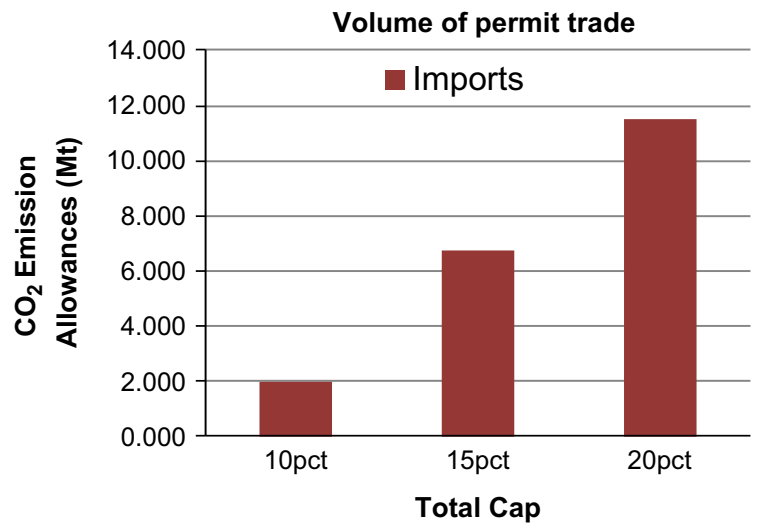

Fig. 5. Turkey's volume of permit imports under the current EU 20-20-20 targets. imports become $1.983 \mathrm{Mt}$ of $\mathrm{CO}_{2}$ under $10 \%$ quota, $6.739 \mathrm{Mt}$ of $\mathrm{CO}_{2}$ and $11.510 \mathrm{Mt}$ of $\mathrm{CO}_{2}$ under $15 \%$ and $20 \%$ quota, respectively. Permit imports increase as the cap increases due to increasing level of MAC of the Turkish ETS sectors.

In comparison to the domestic ETSs, the output levels of the Turkish ETS sectors increase following the decrease in their marginal production costs (Table 9). In particular, they are the sectors of secondary energy generation, iron and steel, non-ferrous metals, chemicals and non-metallic minerals, which abate less than the levels under the S_rETS scenario (Table 10). Due to the decrease in the energy prices, the MAC of the non ETS sectors also tends to decrease. Thus, aggregate economic activity in Turkey increases. Hence, as portrayed in Fig. 1, in comparison to the S_rETS and the C_rETS scenarios, Turkey unambiguously enjoys welfare gains from integration.

Due to the increase in the permit price level, the European ETS sectors decrease their scales of production. While the Turkish ETS sectors are expanding their scales of production at a cost of increasing $\mathrm{CO}_{2}$ emissions, the $\mathrm{EU}$ abates more at a cost of decreasing the production levels of the ETS sectors. The spillover effects are not limited just to the ETS sectors. As Table 5 documents, the MAC of the non ETS sectors also increases under the EU_ETS scenario. The MAC level of the European non ETS sectors, compared to the NOACT scenario, increase from $\$ 84.19$ to $\$ 84.23$ with $10 \%$ quota, to $\$ 84.27$ with $15 \%$ quota, and to $\$ 84.33$ with $20 \%$ quota. Under the S_rETS scenario, regardless of the total cap, MAC is higher and under the $C_{-} r E T S$ scenario, it is lower. This is mainly due to the fact that the European industries become highly dependent on secondary energy imports from Turkey as a result of the EU's abatement policies. Due to expensive electricity imports from Turkey under the S_rETS scenario, the permit price in the European non ETS market increases more compared to the C_rETS scenario. When Turkey integrates with the EU ETS market, the expansion in Turkey's secondary energy sectors lead to cheaper import prices; hence the MAC of the European non ETS sectors decrease compared to the S_rETS scenario.

As displayed in Fig. 1, despite the negative scale effects arising from increasing price levels, the EU still finds it welfare improving when Turkey integrates with the EU ETS compared to the NOACT scenario. This is partly due to the increase in international competitiveness of the European sectors, and partly due to the disposition of the auctioning revenues. However, as Turkey starts to impose stricter emission caps, these welfare gains tend to diminish. In this regard, from the EU's perspective, the cap that Turkey imposes and the manner it is allocated across the ETS and the non-ETS sectors becomes highly critical. On the other hand, in comparison to the S_rETS and C_rETS scenarios, the European Union finds the EU_ETS scenario as welfare reducing. This is mainly due to the burden sharing. The increase in auctioning revenues that European economy enjoys under the EU_ETS scenario cannot compensate for the economic loss arising from

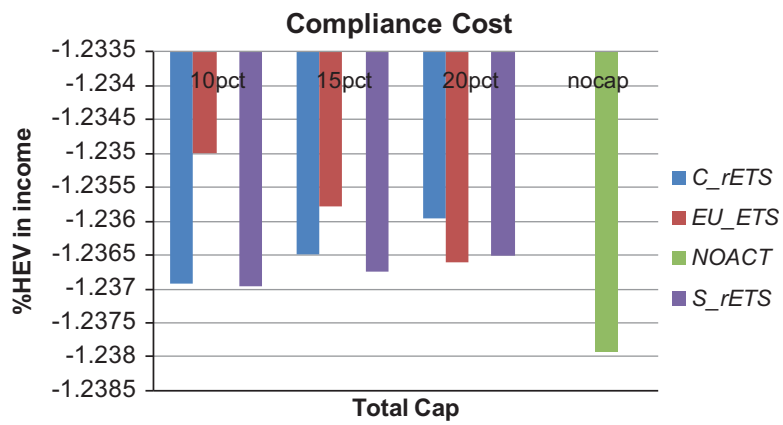

Fig. 6. Welfare effects for the EU under the revised EU 20-20-20 targets. 
the loss in competitiveness of the European industries in the world markets.

\subsection{Policy analysis under the revised EU 20-20-20 targets}

In the second part of our analysis, we assume that the EU increases the emission reduction target for 2020 to 30\% and conduct our economic analysis accordingly.

Following the increase in the emission reduction target, the MAC of the European ETS sectors increases and settles within a range between $\$ 33 / \mathrm{tCO}_{2}$ and $\$ 35 / \mathrm{tCO}_{2}$ (Table 7). The MAC of the non ETS sectors rises on average from $\$ 84 / \mathrm{tCO}_{2}$ to $\$ 266 / \mathrm{tCO}_{2}$. As a result, the EU's welfare loss also increases $220 \%$ on average above its level under the current EU 20-20-20 target. Fig. 6 shows that the EU's welfare loss is around $1.24 \%$ in comparison to the BAU level.

Under the $C_{-} r E T S$ and $S \_r E T S$ scenarios, the EU's welfare undergoes some minor improvements. Taking into account the fairly stable MAC levels of the ETS and non ETS sectors, this should again be attributed to the expanding market share of the European sectors in the domestic markets.

As the EU undergoes stricter emission controls, Turkey expands its total production more and enjoys increasing welfare gains and decreasing welfare losses. As seen in Fig. 7, Turkey's welfare gain under the NOACT scenario increases to $0.30 \%$, while the welfare loss under unilateral abatement efforts decreases to $0.13 \%$ under $10 \%$ cap, to a range between $0.35 \%$ and $0.38 \%$ under $15 \%$ cap and between $0.64 \%$ and $0.73 \%$ under $20 \%$ cap. The additional economic cost arising from segmenting the regional ETS continues to prevail since the non ETS sectors are assigned tighter emission quotas. This is also evident from the MAC levels given inTable 8 .

Our findings reveal that the underlying economic dynamics of the $C \_r E T S$ and $S \_r E T S$ scenarios are pretty similar to our previous findings under the current EU 20-20-20 targets. Nevertheless, the economic incentives under the EU_ETS scenario occur to be somewhat different. Fig. 6 shows that the EU improves its welfare under the EU_ETS scenario with respect to the NOACT scenario. In comparison to the $C_{-} r E T S$ and $S_{-} r E T S$ scenarios, it is still preferable for the EU to have Turkey within the EU ETS under 10\% and 15\% caps due to additional economic gains, while it results in minor welfare losses under the $20 \%$ cap.

The reason underlying this change is that the EU starts to import permits from Turkey due to its high abatement costs. Total permit imports amount to $9.037 \mathrm{Mt}$ of $\mathrm{CO}_{2}$ under $10 \%$ cap and $4.322 \mathrm{Mt}$ of $\mathrm{CO}_{2}$ under $15 \%$ cap (Fig. 8). Nevertheless, rising Turkey's cap to 20\% increases cost burden on the Turkish ETS sectors to $\$ 34.98 / \mathrm{tCO}_{2}$ that is above the EU ETS price level, \$34.18/ $\mathrm{tCO}_{2}$. Hence, the EU finds it more profitable to export $0.406 \mathrm{Mt}$ of $\mathrm{CO}_{2}$ permits to Turkey.

As a permit exporter, Turkey's welfare loss increases under the EU_ETS scenario. However, as Turkey's emission target increases to

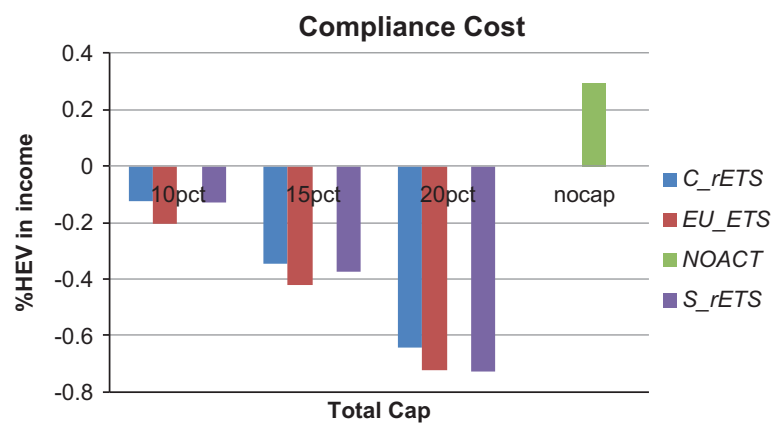

Fig. 7. Welfare effects for Turkey under the revised EU 20-20-20 targets.

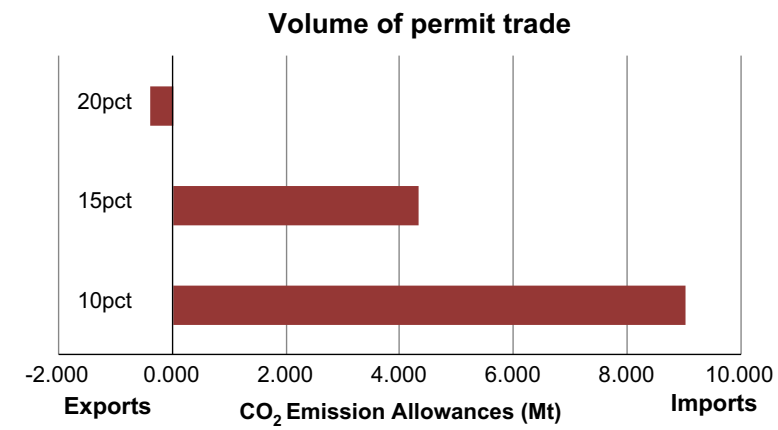

Fig. 8. The EU's volume of permit trading under the revised EU 20-20-20 targets.

$20 \%$, Turkey starts to import permits but this does not result in considerable welfare improvement compared to the S_rETS scenario. Therefore, in contrast to our previous findings, Turkey does not have strong incentives to participate in the EU ETS due to the associated welfare losses.

\section{Conclusions}

In this paper we utilized a multi-regional, multi-sectoral applied general equilibrium model to study the economic impacts of Turkey's permit trading applications and to further investigate the impacts under international cooperation with the EU, via the EU ETS. Our counterfactual scenarios mainly focus on the effects of various emission cutback requirements, the importance of market segmentation in implementing these targets and, finally, the effects of pursuing cooperation with the EU in carbon trading.

These scenarios are simulated for 2020 under the current EU 20-20-20 emission targets and also under the revised targets. It should be noted that the numerical results from this comparative static framework disregards the improvements in renewable technology use and the use of offset credits in the permit markets. Hence, the results should be interpreted accordingly.

In our numerical analysis, we find that Turkey suffers from welfare losses in case of domestic abatement policies and these losses tend to decrease when the EU applies a higher emission reduction target of $30 \%$. From the EU's perspective, Turkey's engagement in domestic abatement activities is always preferable as it enables the EU welfare gains compared to the case where the EU continues to apply its abatement actions without any international cooperation. As Turkey sets higher cutback ratios, the EU's welfare gain gradually increases, due to increased competitiveness of the European industries in the world markets.

Turkey is expected to suffer efficiency losses from market segmentation more as the emission target increases. This is mainly due to increasing price differential between marginal abatement costs of sectors belonging to different market segments. Hence, total compliance cost of meeting the same amount of cap increases. The EU's welfare gains from Turkey's abatement actions also diminish when market segmentation exists. This is a direct effect of increasing marginal abatement costs of some of the European industries due to trade linkages.

Our results indicate that the incentives for Turkey to participate in the EU ETS depend quite much on the EU's total emission target. Under the current EU 20-20-20 emission targets, Turkey will unambiguously gain in comparison to its domestic abatement actions. Since Turkey becomes a permit importer in the EU ETS market, some of its abatement cost burden is carried by the EU. As a result, Turkey experiences expansion in its energy and energy intensive sectors that are integrated with the European carbon market. Depressed marginal abatement costs of energy and energy 
intensive sectors have positive spillover effects on other non energy sectors via cheaper energy prices, as well. Therefore, Turkey becomes better off under international cooperation.

On the other hand, if the EU increases its emission target to $30 \%$, Turkey experiences that participating in the EU ETS is more welfare decreasing compared to the comprehensive and segmented ETSs. The composition of buyers and sellers in the EU ETS is now changed, and the EU becomes a permit importer for low levels of Turkey's emission reduction target. Thus, Turkey has output losses on the one hand, and auctioning revenues on the other, being dominated by the former effect. As Turkey increases its target to $20 \%$, the EU initiates exporting permits to Turkey. However, the improving effect of this change on Turkey's welfare is quite minor and is dominated by the increasing cost burden on the Turkish non-ETS sectors.

As our analysis further reveals, the European Union has welfare gains out of Turkey's domestic mitigation actions due to increased competitiveness of its industries in the world markets. Under the current EU 20-20-20 emission targets, the EU loses some of these welfare gains when Turkey integrates with the EU ETS. As opposed to this, under the revised EU 20-20-20 targets, the EU finds it more welfare improving that Turkey's regional ETS integrates with the EU ETS. In comparison to the current situation where Turkey has not yet taken any abatement action, the EU unambiguously favors that the Turkish ETS links with the EU ETS and the volume of the permit market enlarges. The magnitude of net gains from linkage highly depends on the structural parameters of Turkey's permit trading scheme, i.e. the level of the emission target and its distribution across the sectors. As our analysis reveals, the EU ends up with less welfare gains from linkage as Turkey's mitigation target increases. Hence, the question of how much burden that the Turkish authorities will put on the ETS sectors is highly critical and is open to a controversial public debate.

\section{Acknowledgments}

We benefited from valuable comments and suggestions from Ebru Voyvoda, Selin Sayek Böke, Çağrı Sağlam and participants of the macroeconomic workshops at Bilkent. We also acknowledge the very careful and diligent critical comments of the two unanimous referees of this Journal. Gökçe Akın Olçum would further like to thank Christoph Böhringer for his invaluable guidance on economic modeling techniques and gratefully acknowledges the support of The Scientific and Technological Research Council of Turkey (TUBITAK) for their Graduate Fellowship Program.

\section{References}

Akin Olcum, G., 2012. Market-based environmental regulation in the post-Kyoto world: analysis of Turkey's action plan in general equilibrium framework (Ph.d. thesis). Bilkent University, unpublished.

Anger, N., 2008. Emissions trading beyond Europe: linking schemes in a post-Kyoto world. Energy Economics 30, 2028-2049.

Anger, N., 2009. Linking the EU emissions tradings scheme: economic implications of allowance allocation and global carbon constraints. Mitig Adapt Strateg Glob Change 14, 379-398.
Armington, P.S., 1969. A theory of demand for products distinguished by place of production. Imf Staff Papers/International Monetary Fund (International) 16 (1), 159-178.

Aydin, L., Acar, M., 2010. Economic and environmental implications of Turkish accession to the European Union: a CGE analysis. Energy Policy 38, 7031-7040.

Babiker, M., Reilly, J., Viguier, L., 2004. Is international emissions trading always beneficial? Energy Journal 25, 33-56.

Badri, N.G., Walmsley, T.L., 2008. Global trade, assistance, and production: the GTAP 7 Data Base. Center for Global Trade Analysis, Purdue University.

Baron, R., Bygrave, S., 2002. Towards international emissions trading: design implacations for linkages, OECD Information Paper. OECD, Paris.

Bernard, A., Vielle, M., 2009. Assessment of European Union transition scenarios with a special focus on the issue of carbon leakage. Energy Economics 31, S274-S284.

Blyth, W., Bosi, M., 2003. Linking non-EU domestic emissions trading schemes with the EU emissions trading scheme, Environment Directorate International Energy Agency.

Böhringer, C., Loschel, A., Moslener, U., Rutherford, T.F., 2009. EU climate policy up to 2020: An economic impact assessment. Energy Economics 31, S295-S305.

Bohringer, C., Rutherford, T.F., 2002. Carbon abatement and international spillovers -A decomposition of general equilibrium effects. Environmental \& Resource Economics 22, 391-417.

Böhringer, C., Rutherford, T.F., 2010. The costs of compliance: a CGE assessment of Canada's policy options under the Kyoto protocol. World Economy (UK) 33 (2) $177-211$.

EIA, 2010. International Energy Outlook. U.S. Energy Information Administration, Washington, DC.

European Commission, 2008. The Climate Action and Renewable Energy Package, Europe's climate change opportunity. 〈http://ec.europa.eu/clima/policies/pack age/index_en.htm>.

European Commission, 2009. Directive 2009/29/EC of the European Parliament and the Council amending Directive 2003/87/EC so as to improve and extend the Greenhouse Gas Emission Allowance trading Scheme of the Community. L140/ 63, Official Journal of the European Union.

European Commission, 2012. The state of the European carbon market in 2012.

Eyckmans, J., Hagem, C., 2011. The European Union's potential for strategic emissions trading through permit sales contracts. Resource and Energy Economics 33, 247-267.

Haites, E., 2001. Linking domestic and industry greenhouse gas emission trading systems. Prepared for Electric Power Research Institute (EPRI), International Energy Agency (IEA) and International Emissions Trading Association.

IEA, 2011a. $\mathrm{CO}_{2}$ emissions from fuel combustion: a new basis for comparing emissions of a major greenhouse gas. IEA statistics, p. v. OECD, Paris, France.

IEA, 2011b. Economic indicators. Energy Projections for IEA Countries. International Energy Agency, Paris, France.

IEA, OECD, 2011. Energy balances of OECD countries. p. v. OECD, Paris, France.

IMF, 2012. World economic outlook: Growth resuming, dangers remain. World Economic And Financial Surveys. International Monetary Fund, Washington, DC

Kumbaroglu, G.S., 2003. Environmental taxation and economic effects: a computable general equilibrium analysis for Turkey. Journal of Policy Modeling 25 795-810.

Lee, H., Oliviera-Martins, J., Van der Mensbrugghe, D., 1994. The OECD Green model: an updated overview.

Ministry of Environment and Urbanization, 2011. National climate change action plan. 〈http://iklim.cob.gov.tr/iklim/Files/IDEP/\%C4\%BODEPENG.pdf〉.

Montgomery, W.D., 1972. Markets in licenses and efficient pollution control programs. Journal of Economic Theory 5, 395-418.

Paltsev, S., Reilly, J.M., Jacoby, H.D., Eckaus, R.S, McFarland, J., Sarofim, M., Asadoorian, M., Babiker, M., 2005. The MIT emissions prediction and policy analysis (EPPA) model: version 4. The MIT Joint Program on the Science and Policy of Global Change, Cambridge, MA.

Rutherford, T.F., 2011. GTAP7inGAMS package.

Telli, C., Voyvoda, E., Yeldan, E., 2008. Economics of environmental policy in Turkey: a general equilibrium investigation of the economic evaluation of sectoral emission reduction policies for climate change. Journal of Policy Modeling 30 321-340.

Vural, B., 2009. Tracing the second dividend in environmental policies: a CGE application to Turkey (M.A. thesis). Bilkent University, unpublished.

World Bank, 2012. State and trends of the carbon market. World Bank, Washington, D.C.. 